ecosystems to how they were before humans intervened. Natural ecological processes could be revived in US prairies, for instance, by replacing long-extinct mammoths, sabretooth cats and rhinos with their twenty-firstcentury ecological equivalents from Africa. One should not deny a man his fantasies, but the reality of restoring large species provides more immediate, yet still important challenges, including how much land is needed for various species.

The American Prairie Foundation is restocking prairies with pure-bred bison and smaller species, such as prairie dogs and their highly endangered predators, the black-footed ferret. The Wildlands Project is a US effort to connect existing wild areas from Alaska to Mexico to make them large enough to support large viable populations of predators. Its South African equivalent, the Peace Parks Foundation, notes that even the national parks of Africa are not always large enough to support lion and wild dog populations, and wants to connect them into 'mega parks'.

Another South African experience is not widely appreciated. During that nation's decades of political and academic isolation, game biologists conducted hundreds of mostly successful reintroductions of many herbivore species, including rare black rhino, black wildebeest and bontebok antelope, to their historical range in dozens of provincial parks. Numerous private game reserves have now extended those experiments, raising practical but difficult questions about how large reserves must be to hold predators or even their prey.

A few years ago, I sat munching on my lunchtime sandwich, watching wildlife that ought only appear together in a dream. Fifty wild horses stared at me. The red deer grazing behind them were oblivious. Farther away a large flock of barnacle geese had stopped to breed, and overhead soared a breeding pair of sea eagles. Wild horses have long disappeared from Europe; in the twentieth century, barnacle geese bred only in the high Arctic, and deer and eagles were found only at the sparsely populated fringes of the continent. Some 5 metres below sea level, the Oostvaarderplassen nature reserve in the Netherlands is an unlikely place to have restored something close to Europe's post-Pleistocene fauna. That these big, wild things now live there shows that nearly anything is possible. Surely, the exciting story is where the wild things were, and will be once again.

Stuart Pimm is professor of conservation ecology at the Nicholas School of the Environment, Duke University, Durham, North Carolina 27708, USA.

\title{
Science wars revisited
}

Beyond the Hoax: Science, Philosophy,
and Culture
by Alan Sokal
Oxford University Press: 2008.488 pp.
$\$ 39.95, £ 20.00$

What a difference a decade makes. In the mid-1990s, scientists and academics studying scientific culture were at each other's throats. The scientists thought the sociologists, historians and literary critics were ludicrously ignorant of science, making all kinds of nonsensical pronouncements. The other side dismissed these charges as naive, ill informed and selfserving. The exchanges became known as the science wars.

In 1996, physicist Alan Sokal landed in the centre of this fray by fooling the editors of the journal Social Text into publishing as a serious contribution his hilarious parody of cultural studies of science. His new collection of essays, Beyond the Hoax, lets us know what he has been up to on the cultural front in the decade since.

At the peak of the science wars, in 1997 Sokal and I both attended an extraordinarily interdisciplinary symposium in Santa Cruz, California. Sparks flew and proclamations of the imminent end of civilization were voiced by many in a large auditorium packed with partisans. Later that year I joined a smaller, less contentious gathering at the University of Southampton, UK, which resulted in a book. In The One Culture? A Conversation About Science, a diverse group, including Sokal and me, stated positions, commented on the positions of the others, and commented on the comments. I date the return of peace to academia to 2001, the year this book came out.

Other things happened in 2001 to take the steam out of the science wars. The new administration of George W. Bush decreed strict constraints on federal support for US research on embryonic stem cells, in an early example of its readiness to place ideology over science (and other forms of expertise). This provided a tough new standard against which to measure threats to science. And on a single morning, 3,000 people were murdered by terrorists in the United States in a horrifying demonstration of the real fragility of civilization. As a sign that the science wars are over, I cite the 2008 election of Bruno Latour - one of Sokal's favourite bêtes noires - to Foreign Honorary Membership in that bastion of the establishment, the American Academy of Arts and Sciences.
Beyond the Hoax gives us a memento of those fraught but innocent days of the 1990s. It begins with a reprint of the famous parody, accompanied by a rambling commentary that could itself be a parody of pedantic literary explication. This facing-page exegesis is set in so tiny a font that it gets farther and farther ahead of the text, ending halfway through the article so that all pages from 50 to 90 that would have had even numbers are blank. The commentary explains the jokes, teaches bits of physics, expands on cited texts, and addresses subsequent criticisms. Hoax fans ought to enjoy it.

In a preface, Sokal announces his "visceral distaste for books that have been confected by pasting together a collection of loosely connected, previously published essays". His book, he explains, is different. These ten essays (seven previously published) "form, I believe, a coherent whole". But virtually everyone who publishes a collection of essays believes they form a coherent whole. Sokal's obliviousness to this is an early indication of a complacency about his own views, and a lack of imagination about what others might be thinking, that undermines much of what follows.

Take, for example, what he says about Arkady Plotnitsky's interpretation of an obscure reply by the controversial, charismatic, deconstructionist philosopher Jacques Derrida, lampooned as meaningless nonsense in Sokal's hoax and by earlier science warriors. Derrida was asked whether Einstein's view of space-time might contain an example of a subtle Derridean concept, 'the centre of structure'. Sokal acknowledges that Plotnitsky "has a fair knowledge of physics", but this fails to capture the unique role Plotnitsky played in the 1990s as the sole participant in the conversation who was as comfortable with theoretical physics and mathematics as he was with literary theory, sociology and science history. Plotnitsky took several pages to elucidate the technical concept of a 'centre', on which the much-maligned comment hinges, before suggesting what Derrida might have been getting at. This demonstration that Derrida's remark need not sound absurd if you are as well acquainted with Derrida as you are with Einstein, is dismissed by Sokal for three reasons: Plotnitsky gives two possible readings, "he offers no evidence that Derrida intended (or even understood) either of them", and Derrida was alive at the time so "why not just ask him?".

Or take Sokal's remarks about the physicist, biologist, and historian and philosopher of 
science, Evelyn Fox Keller. Keller suggested there may be a style of doing science that made it more congenial to male than female practitioners. Sokal acknowledges her excellent credentials as a scientist: "[Keller] is a different can of worms entirely." But he concludes from her reference to "the values articulated by early modern scientists" that she "implies that the issue is one of ethics, rather than of epistemology", missing the point that epistemology is not always so easily disentangled from values. He calls her association of science with the mastery and control of nature "a gross exaggeration" on the grounds that early Newtonian mechanics applied to astronomical phenomena "over which we have no control whatsoever”. He rejects Keller's speculation that a different style of doing science might result in a different science, because it "has no meaning except insofar as one can imagine that a different ideology might have led (in an imaginary counterfactual world) to a different course of scientific development". But Keller's well-known biography of the biologist Barbara McClintock is, in part, an exploration of this proposition in the real factual world.

Sokal also takes on Keller's essay "Cognitive repression in contemporary physics", a tour de force that invokes Jean Piaget's views of cognitive development to shed a different light on difficulties in the interpretation of quantum mechanics. In 1991, the American Journal of Physics declared the essay to be one of their six memorable papers of 1979. Overlooking Keller's wit, her fresh perspective and the fact that the paper was published nearly 30 years ago, before the current burst of interest in foundations of quantum mechanics, Sokal brusquely dismisses it as "exceedingly meager", with views that are neither new nor insightful.

Admittedly, Plotnitsky and Keller are two of Sokal's more formidable targets. And I should note that elsewhere in the book he is just as critical of those for whom he has sympathy as he is of those he finds - and I often agree - irredeemably foolish. He has an admirable passion for clarity of thought, and is commendably opposed to those who would pass off nonsense as profundity, whether they be commentators on science, spokesmen for religion, or the governments of nations. But Sokal's unwillingness to expand his frame of reference to accommodate legitimately different points of view undermines his effectiveness as a scourge of genuine rubbish.

I would like to think that we are not only beyond Sokal's hoax, but beyond the science wars themselves. This book might be a small step backwards.

N. David Mermin is Horace White Professor of Physics Emeritus at Cornell University, Ithaca, New York 14853-2501, USA. His latest book is Quantum Computer Science: An Introduction.

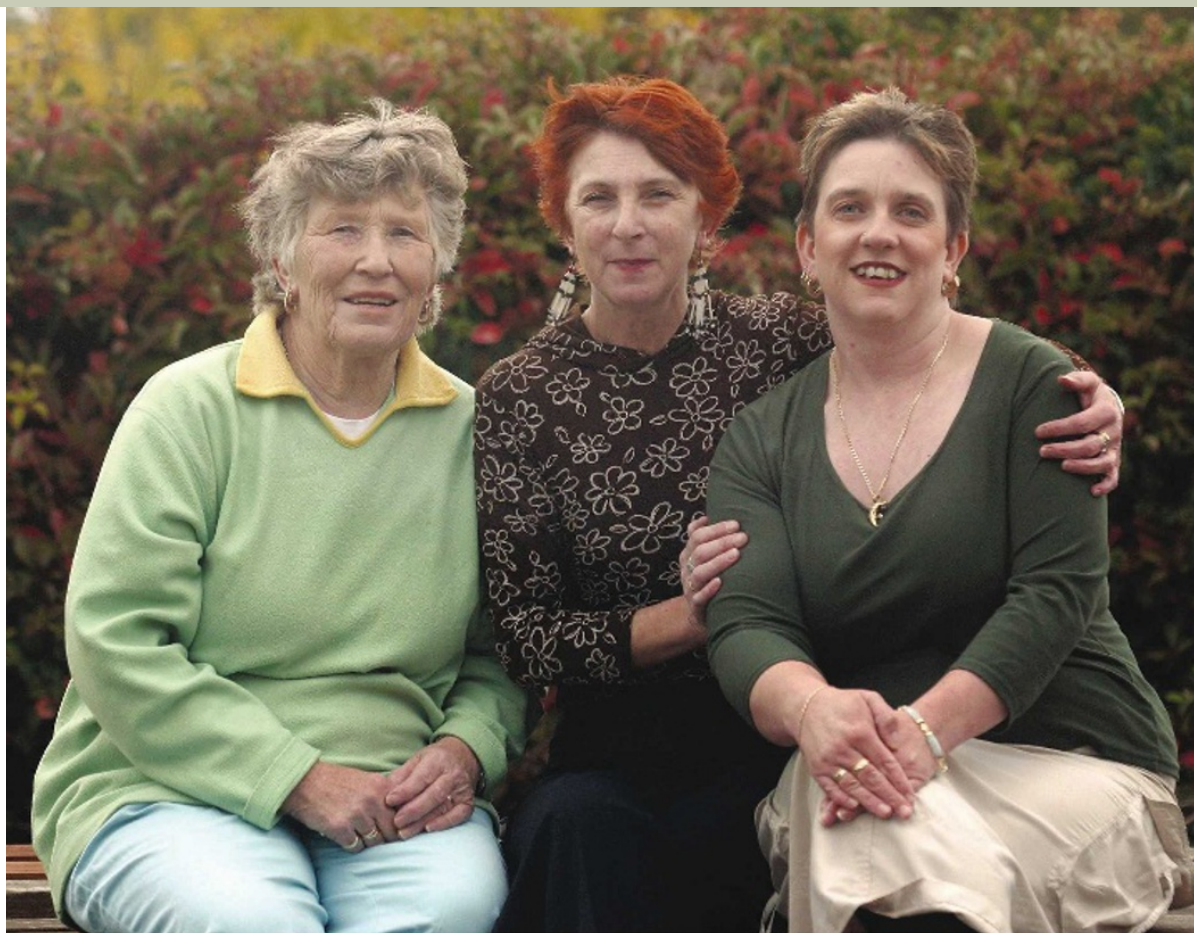

Three women in this family had breast cancer. Would they have been helped by a genetic diagnosis?

\section{To know or not to know?}

\section{Blood Matters: From Inherited Illness to \\ Designer Babies, How the World and I Found Ourselves in the Future of the Gene by Masha Gessen \\ Harcourt: 2008. 321 pp. $\$ 25.00$}

In 2004, journalist Masha Gessen published a personal account in the online magazine Slate of an increasingly common modern medical dilemma: how to respond to genetic diagnoses that offer both too much and not enough information. Gessen, a 37-year-old with a mutant form of the BRCA1 gene that is associated with an increased risk of breast cancer, promised to announce in the next issue whether she would undergo preventative surgery to remove her breasts and her ovaries to reduce her chances of developing cancer. Her book Blood Matters, now published four years on, explores the difficulties this decision involved.

Gessen encountered similar issues to those described in an earlier first-person narrative of genetic diagnosis, Mapping Fate by Alice Wexler (University of California Press, 1995). Wexler chronicled her experience of living in a family affected by Huntington's disease in the wake of the 1983 discovery of a genetic marker for the condition. She had a frontrow seat from which to produce an account of what it means to have one's fate mapped genetically: her mother died from Huntington's, her sister is one of the leading scientists who helped to find the Huntington's gene, and the research was partly funded by the Hereditary Disease Foundation established by their father. At the centre of Wexler's narrative lies a powerful lesson about the burdens of genetic knowledge. Paradoxically, the difference between abstract genetic information and real personal experience could be described as a knowledge gap. For the Wexlers, this gap was illustrated by the fact that, having found the gene and developed the test, neither sister was prepared to take it.

'To know or not to know' has thus become an added dimension of inherited pathology, creating new kinds of bonds and conflicts over the meanings of inherited genetic substance, among family members and unrelated people who share the same condition. This ambivalence is created by the very means intended to alleviate the burden of suffering to begin with - the production of detailed and accurate knowledge of how genes work. As in prenatal testing, the surfeit of explicit, readily accessible and sophisticated technical and scientific knowledge can make decisions that are based on genetic information more, rather than less, difficult.

Gessen's exploration of her own genetic inheritance, and her world tour of genetic research facilities and hospital clinics, highlight the dilemma of genetic decision-making more vividly than any such narrative to date. She comes to realize that the frontier of genetic medicine for her condition is "essentially surgical". She moves beyond weighing up the pros and cons to investigating the paradigms that shape genetic research, taking the reader on a breakneck tour of medical, biological, statistical, psychological and economic perspectives on genes, genetic risk 